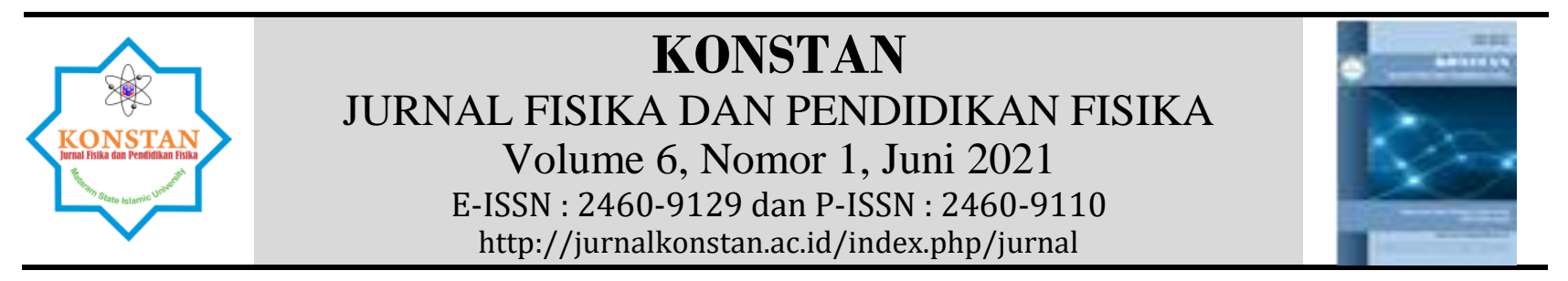

\title{
Pengembangan Perangkat dengan Model Pembelajaran Advance Organizer untuk Meningkatkan Penguasaan Konsep dan Retensi Fisika Peserta Didik
}

\author{
Syari'atul Fitria ${ }^{1, *)}$, Ahmad Harjono' ${ }^{2}$, Gunawan ${ }^{3}$, Syahrial Ayub ${ }^{4}$ \\ ${ }^{1,2,3,4}$ Program Studi Pendidikan Fisike Universitas Mataram, Jalan Majapabit No. 62 Mataram NTB \\ Indonesia \\ *syariatulfitria20@gmail.com
}

\begin{abstract}
Info Artikel: Abstract
Dikirim:

10 Januari 2021

Revisi:

18 April 2021

Diterima:

20 April 2021

Kata Kunci:

Pengembangan

Perangkat

Pembelajaran,

Advance

Organizer,

Penguasaan

Konsep, Retensi

Penelitian ini bertujuan untuk mengetahui kelayakan perangkat dengan model pembelajaran advance organizer untuk meningkatkan penguasaan konsep dan retensi fisika peserta didik. Perangkat pembelajaran yang dikembangkan meliputi silabus, RPP, LKPD, peta konsep, instrumen tes penguasaan konsep dan retensi fisika. Desain penelitian yang digunakan adalah Research and Development (R\&D) dengan model 4D (define, design, develop \& disseminate). Penelitian ini dibatasi hanya pada tahap pengembangan yaitu validasi oleh validator dengan data pendukung berupa respon mahasiswa dan peserta didik terhadap perangkat yang dikembangkan. Hasil validasi menggunakan CVR dan CVI menunjukkan perangkat termasuk kategori sangat layak. Rata-rata hasil perhitungan respon dari mahasiswa dan peserta didik yaitu 99\%. Berdasarlkan hasil validasi dan respon mahasiswa serta peserta didik, dapat disimpulkan bahwa perangkat dengan model $\mathrm{AO}$ yang dikembangkan sangat layak digunakan dalam pembelajaran fisika. Perangkat yang dikembangkan dengan kategori layak diharapkan dapat meningkatkan penguasaan konsep dan retensi fisika peserta didik.
\end{abstract}

(C) 2021 Universitas Islam Negeri Mataram

\section{PENDAHULUAN}

Sains merupakan ilmu pengetahuan yang mempelajari tentang sebab akibat fenomena yang terjadi di alam. Salah satu cabang dari sains yaitu fisika. Fisika memiliki hakikat sebagai kumpulan pengetahuan, cara penyelidikan dan cara berpikir [1]. Fisika tidak hanya menekankan pada pengetahuan yang bersifat hafalan saja melainkan pada proses terbentuknya pengetahuan dan penguasaan konsep pada peserta didik. Pelajaran fisika adalah pelajaran yang dapat mengajarkan berbagai pengetahuan yang dapat mengembangkan daya nalar, sehingga hampir semua persoalan yang berkaitan dengan alam dapat dimengerti dan diselesaikan oleh peserta didik [2]. Pembahasan dan arahan pembelajaran fisika hendaknya didasarkan pada pemahaman konsep-konsep bukan pada penggunaan rumus-rumus fisika yang memiliki kecenderungan menggeser pembelajaran fisika menjadi pembelajaran matematika.

Guru lebih menekankan pelajaran fisika sebagai pelajaran yang hanya berisi rumus dan soal saja tanpa ada pemahaman konsep yang ditekankan. Hal ini menyebabkan peserta didik merasa bosan dan kesulitan dalam belajar fisika. Salah satu kekurangan yang ada dalam dunia pendidikan adalah peserta didik hanya menghafal tanpa memahami atau menguasai isi pelajaran [3]. Proses belajar tidak hanya sekedar menghafal konsep atau fakta-fakta belaka (root learning), namun berusaha menghubungkan konsep-konsep atau fakta-fakta tersebut untuk menghasilkan pemahaman yang utuh, sehingga konsep yang dipelajari dipahami secara baik dan tidak mudah dilupakan [4]. Peserta didik akan dengan mudah menguasai konsep-konsep fisika apabila dapat membangun konsepkonsep tersebut dengan bahasanya sendiri tanpa mengubah makna yang ada di dalamnya dan 
mampu menyelesaikan persoalan-persoalan fisika yang ditemukan untuk dapat diaplikasikan dalam kehidupan sehari-hari [5]. Untuk menguasai dan mengingat konsep-konsep tersebut dalam jangka waktu yang lama, pembelajaran yang dilakukan harus bermakna.

Pembelajaran bermakna (meaningful learning) menganjurkan pentingnya pemahaman konsepkonsep dan hubungan antar konsep terutama dalam pembelajaran fisika yang merupakan salah satu cabang dari pembelajaran sains [6]. Pembelajaran bermakna adalah belajar yang disertai dengan pengertian dan akan terjadi apabila informasi yang baru diterima mempunyai kaitan yang erat dengan konsep yang sudah ada atau sudah diterima dan tersimpan dalam struktur kognitif peserta didik. Sangat penting bagi guru untuk mengetahui konsep-konsep yang telah dimiliki peserta didik supaya pembelajaran bermakna dapat berlangsung. Pengetahuan awal berperan penting dalam belajar karena menunjang kemudahan dalam menerima dan memahami suatu materi atau konsep baru dalam pembelajaran [7]. Kemampuan dalam menerima materi baru dan mengaitkan materi tersebut dengan pengetahuan yang telah ada pada struktur kognitif tentu akan memengaruhi penguasaan konsep peserta didik.

Peserta didik dapat menguasai konsep fisika secara baik dan benar apabila guru dapat menciptakan keselarasan dan koneksi dengan mengorganisasikan antara pengetahuan yang sudah dimiliki dengan pengetahuan baru yang akan diterima selama pembelajaran. Oleh karena itu, diperlukan suatu model yang dapat menunjang keterlaksanaan pembelajaran bermakna dengan tujuan menyelaraskan pengetahuan awal dengan pengetahuan yang sudah ada pada struktur kognitif peserta didik. Model pembelajaran yang dapat digunakan adalah model pembelajaran advance organizer (AO), post organizer (PO) dan ekspositori. Pada penelitian ini, membahas mengenai model pembelajaran AO.

AO dianggap sebagai alat yang dapat memberikan suatu bahan pendahuluan terhadap apa yang dipelajari untuk membantu peserta didik mengorganisasi, mengingat dan mengaitkan pengetahuan sebelumnya terhadap pengetahuan baru yang dipelajari [8]. AO sebagai informasi yang disajikan berupa konsep-konsep dan hubungan antar konsep sebelum pembelajaran yang digunakan untuk mengintegrasikan pengetahuan baru dengan pengetahuan yang sudah ada dalam struktur kognitif peserta didik [9]. AO bertujuan untuk memperkuat struktur kognitif peserta didik dan menambah daya ingat (retensi) peserta didik terhadap informasi yang bersifat baru [10]. Pengembangan perangkat dengan model pembelajaran AO ini diharapkan dapat meningkatkan penguasaan konsep dan retensi fisika peserta didik. Penelitian Oloyede menyebutkan bahwa dari 138 peserta didik, AO dapat meningkatkan retensi mereka [11].

\section{METODE PENELITIAN}

Penelitian ini merupakan penelitian pengembangan atau lebih dikenal dengan Research and Development $(\mathrm{R} \& \mathrm{D})$ yang mengadaptasi model 4-D dengan tahapan penelitian yaitu pendefinisian (define), perancangan (design), pengembangan (deveolop) dan penyebaran (disseminate) [12]. Tahap define merupakan tahap untuk menemukan masalah dalam pembelajaran fisika. Pada tahap design dilakukan perancangan atau pembuatan produk yaitu perangkat dengan model AO. Pada tahap develop dilakukan validasi produk oleh validator, penyebaran angket respon pada mahasiswa dan peserta didik, serta revisi perangkat berdasarkan saran dan masukan dari validator. Perangkat pembelajaran yang dikembangkan yaitu silabus, RPP, LKPD, peta konsep, instrumen tes penguasaan konsep dan retensi fisika.

Validitas perangkat dengan model pembelajaran AO dihitung menggunakan Content Validity Ratio (CVR) dan Content V alidity Index (CVI) [13].

$$
C V R=\frac{N e-\frac{N}{2}}{\frac{N}{2}}
$$


Keterangan:

$\mathrm{Ne}$ : jumlah validator yang setuju (dianggap setuju/layak jika nilai setiap aspek dari kisaran 3-4, jika $<3$ dianggap tidak setuju/tidak layak). Jika setuju bernilai 1 dan jika tidak setuju bernilai nol.

$\mathrm{N}$ : jumlah total validator

Selanjutnya, dihitung CVI yang merupakan indikasi validitas isi yaitu rata-rata nilai CVR dari semua item. Rumus dari CVI adalah sebagai berikut:

$$
\mathrm{CVI}=\frac{\text { jumlah seluruh CVR }}{\text { jumlah butir item }}
$$

Kategori hasil perhitungan CVR dan CVI adalah dengan rentang $-1<x<1$. Angka tersebut dikategorikan dengan kriteria $0<x<1=$ sangat layak; $0=$ layak dan $-1<x<0=$ tidak layak.

Reliabilitas dalam penelitian ini dihitung menggunakan metode Borich yang dikenal dengan Percentage Agreement (PA) yaitu persentase kesepakatan antar penilai yang merupakan suatu persentase kesesuaian nilai antara penilai pertama dan penilai kedua. Perangkat dikatakan reliabel jika nilai persentase kesepakatan lebih atau sama dengan 75\%. Jika dihasilkan kurang dari 75\%, maka harus diuji kejelasan dan persetujuan dari pengamat [14]. PA dapat dirumuskan :

Keterangan:

$$
\mathrm{PA}=\left(1-\frac{A-B}{A+B}\right) 100 \%
$$

A : skor penilai yang lebih besar

B : skor penilai yang lebih kecil

Penelitian ini dibatasi sampai tahap validasi. Uji terbatas pada mahasiswa ataupun peserta didik tidak dilakukan karena situasi dan kondisi yang tidak memungkinkan. Untuk mendukung data validasi oleh validator, dilakukan penyebaran angket respon pada mahasiswa dan peserta didik yang telah mempalajari materi usaha dan energi terhadap perangkat yang dikembangkan. Persentase respon dihitung menggunakan persamaan:

$$
\mathrm{PR}=\frac{\text { banyak respon positif }}{\text { banyak responden }} \times 100 \%
$$

Selanjutnya, hasil perhitungan PR dapat dikategorikan sebagai berikut: $81 \%-100 \%=$ sangat baik; $61 \%-80 \%=$ baik; $41 \%-60 \%=$ kurang baik ; dan $\leq 20 \%=$ sangat kurang baik [15].

\section{HASIL DAN PEMBAHASAN}

Penelitian ini merupakan penelitian pengembangan yang dilakukan karena situasi dan kondisi yang tidak memungkinkan untuk melakukan pembelajaran secara langsung, dengan harapan adanya perangkat yang dikembangkan dapat diterapkan saat situasi dan kondisi sudah kembali normal. Penelitian pengembangan sebagai suatu proses atau langkah-langkah untuk mengembangkan suatu produk baru atau menyempurnakan produk yang telah ada dan dapat dipertanggungjawabkan [16]. Produk yang dimaksud dalam penelitian ini adalah perangkat dengan model pembelajaran AO berupa silabus, RPP, peta konsep, LKPD, instrumen tes penguasaan konsep dan instrumen tes retensi fisika. Selain untuk menghasilkan produk, tujuan dari penelitian ini yaitu untuk mengetahui kelayakan dari perangkat yang dikembangkan.

AO merupakan model yang membantu peserta didik dalam mengaitkan pengetahuan baru dengan pengetahuan yang sudah ada pada struktur kognitif sehingga terjadi pembelajaran yang bermakna. Pembelajaran bermakna adalah belajar yang disertai dengan pengertian dan akan terjadi apabila informasi yang baru diterima mempunyai kaitan yang erat dengan konsep yang sudah ada 
atau sudah diterima dan tersimpan dalam struktur kognitif peserta didik [6]. AO bertujuan untuk memperkuat struktur kognitif peserta didik dan menambah daya ingat (retensi) terhadap informasi yang bersifat baru [10]. Penelitian Oloyede membuktikan dari 138 peserta didik SMA didapatkan hasil bahwa $A O$ dapat meningkatkan retensi mereka [11]. Penelitian sebelumnya menyatakan bahwa perangkat dengan model inkuiri dipadu AO layak dan praktis digunakan dalam pembelajaran [17].

AO memiliki tiga tahapan dalam pembelajaran [18]. Tahap pertama yaitu penyajian AO, dimana guru mengklarifikasi tujuan pembelajaran serta menyajikan AO dalam bentuk peta konsep. Tahap kedua yaitu penyajian tugas atau materi pembelajaran. Tahap ini dilakukan dengan cara progressive differensial, yaitu pengembangan konsep berlangsung paling baik bila dimulai dengan cara menjelaskan terlebih dahulu hal-hal yang umum terus sampai pada hal-hal yang bersifat khusus, kemudian dijelaskan disertai dengan contoh-contoh [19]. Tahap ketiga yaitu penguatan struktur kognitif. Pada tahap ini dilakukan dengan prinsip-prinsip rekonsiliasi integratif, dimana konsepkonsep terorganisasi agar dapat membantu penerimaan dan penyimpanan penguasaan konsep dalam memori struktur kognitif peserta didik [20]. Ketika penerimaan dan penyimpanan konsep terjadi dengan baik, tentu akan berpengaruh terhadap penguasaan konsep dan tingkat bertahannya konsep tersebut dalam struktur kognitif peserta didik.

Pembelajaran menggunakan AO dapat membuat belajar bersifat hafalan menjadi bermakna dengan cara menjelaskan hubungan konsep baru dengan konsep relevan yang ada dalam struktur kognitif peserta didik, agar dapat memahami konsep lebih efektif dan efisien [21]. Lebih lanjut, Ausubel menjelaskan AO dapat memberikan 3 macam manfaat, yaitu 1) menyediakan suatu kerangka konseptual untuk materi belajar yang akan dipelajari oleh peserta didik, 2) berfungsi sebagai jembatan yang menghubungkan antara apa yang sedang dipelajari peserta didik saat ini dengan apa yang akan dipelajari peserta didik, 3) membantu peserta didik untuk memahami bahan belajar secara lebih mudah [22].

Penelitian ini terdiri dari tiga tahapan, yaitu define, design, dan develop. Pada tahap define, didapatkan hasil bahwa peserta didik memiliki penguasaan konsep dan retensi yang cukup rendah. $\mathrm{Hal}$ ini dilihat dari respon peserta didik ketika diberi pertanyaan terkait materi sebelumnya maupun materi baru yang akan diajarkan. Pada tahap design, dihasilkan perangkat pembelajaran berupa silabus, RPP dengan model AO, LKPD, peta konsep, instrumen tes penguasaan konsep dan instrumen tes retensi fisika. Tahap develop, didapatkan hasil validasi oleh validator dan hasil respon mahasiswa pendidikan fisika serta peserta didik yang telah mempelajari materi usaha dan energi terkait dengan perangkat yang telah dikembangkan.

Perangkat yang dikembangkan divalidasi oleh 6 orang validator yaitu 3 dosen fisika dan 3 guru fisika. Validasi merupakan tahapan penilaian produk yang dihasilkan dari tahap perancangan oleh validator berdasarkan validitas isi [23]. Selain itu, perangkat pembelajaran perlu divalidasi untuk menjamin kualitasnya. Perangkat dikatakan layak digunakan dalam pembelajaran apabila hasil analisis memenuhi kategori validitas tinggi dan reliabel [24]. Perhitungan validitas isi pada penelitian ini menggunkan CVR dan CVI. Hasil validasi perangkat dapat dilihat pada Tabel 1.

Tabel 1. Hasil Validasi dan Perhitungan Reliabilitas Perangkat Pembelajaran

\begin{tabular}{|c|c|c|c|c|c|}
\hline \multirow{2}{*}{ No } & \multirow{2}{*}{ Perangkat } & \multicolumn{2}{|c|}{ CVI } & \multirow{2}{*}{$\begin{array}{c}\text { Reliabilitas } \\
(\%)\end{array}$} & \multirow{2}{*}{ Kategori } \\
\hline & & Dosen & Guru & & \\
\hline 1 & Silabus & 1 & 1 & 95 & Sangat Layak/ Reliabel \\
\hline 2 & RPP & 0.95 & 1 & 96 & Sangat Layak/ Reliabel \\
\hline 3 & LKPD & 1 & 1 & 94 & Sangat Layak/ Reliabel \\
\hline 4 & Peta Konsep & 0.93 & 1 & 91 & Sangat Layak/ Reliabel \\
\hline 5 & $\begin{array}{c}\text { Instrumen Tes Penguasaan } \\
\text { Konsep }\end{array}$ & 1 & 1 & 93 & Sangat Layak/ Reliabel \\
\hline 6 & Instrumen Tes Retensi & 1 & 1 & 91 & Sangat Layak/ Reliabel \\
\hline
\end{tabular}

Berdasarkan Tabel 1, dapat diketahui bahwa nilai CVI setiap perangkat masuk dalam kategori sangat layak dan reliabel. Perangkat yang dikembangkan dengan kategori layak dan reliabel dapat digunakan dalam pembelajaran fisika [25]. Nilai CVI yang paling kecil diperoleh pada peta konsep 
dikarenakan kualitas penyusunan peta konsep yang belum disertai dengan contoh-contoh, dan pemilihan kata yang belum baik. Peta konsep dapat digunakan sebagai alat untuk memecahkan masalah di dalam pendidikan sebagai pilihan solusi atau sebagai alternatif [26]. Penggunaan peta konsep dalam pembelajaran dapat membantu peserta didik memahami konsep lebih mudah. Penelitian sebelumnya menyatakan bahwa penerapan model pembelajaran AO berbantuan peta konsep berpengaruh positif terhadap hasil belajar fisika [11]. Hasil belajar yang dimaksud salah satunya adalah penguasaan konsep.

Penguasaan konsep merupakan usaha yang harus dilakukan peserta didik dalam merekam dan mentransfer kembali sejumlah informasi dari suatu mata pelajaran tertentu yang dapat dipergunakan dalam memecahkan masalah, menganalisis, menginterpretasikan pada suatu kejadian tertentu [27]. Penguasaan konsep sangat penting sebagai bekal dalam menyelesaikan masalah tertentu karena dalam menyelesaikan masalah dibutuhkan konsep yang mendasari masalah tersebut [28]. Instrumen tes penguasaan konsep menggunakan tes pilihan ganda sebanyak 20 soal untuk ranah kognitif dari C1-C6 sesuai taksonomi Bloom revisi. Penguasaan konsep yang baik akan membuat apa yang dipelajari tersimpan dalam memori dengan baik pula. Hal ini tentu erat kaitannya dengan retensi peserta didik yang akan membantu mereka dalam menyelesaikan permasalahan yang ditemukan.

Retensi menjadi bagian penting dalam pembelajaran karena merupakan pijakan dalam mendapatkan pengetahuan. Retensi diartikan sebagai banyaknya pengetahuan yang dipelajari oleh peserta didik yang tersimpan dalam memori jangka panjang dan dapat diungkapkan kembali pada selang waktu tertentu. Instrumen tes retensi dalam pembelajaran sebaiknya diberikan minimal dua minggu setelah tes penguasaan konsep, dengan soal yang sama seperti soal tes penguasaan konsep [3]. Retensi peserta didik tergolong tinggi jika hasil perhitungan lebih dari atau sama dengan $70 \%$, dimana perhitungan retensi yaitu hasil tes retensi dibagi dengan hasil tes penguasaan konsep dikali dengan 100\% [29]. Retensi dapat berupa pengetahuan awal yang dimiliki peserta didik. Pengetahuan awal yang baik menunjukkan retensi peserta didik terhadap materi sebelumnya baik, sehingga hasil belajar akan tinggi. Ketika pengetahuan awal rendah, dapat dikatakan retensi peserta terhadap materi sebelumnya rendah sehingga akan berdampak pada rendahnya hasil belajar. Untuk mengatasi hal tersebut, maka diperlukan model pembelajaran yang memperhatikan pengetahuan awal dan menambah retensi peserta didik yaitu AO.

Perangkat dengan model AO yang divalidasi telah mengalami revisi pada berbagai aspek sesuai dengan masukan dari validator. Penilaian dan saran dari validator dijadikan sebagai masukan dan dasar untuk merevisi perangkat pembelajaran, sehingga dapat digunakan pada uji kelompok kecil dan uji lapangan [30]. Adapun saran validator terhadap perangkat yang dikembangkan antara lain, melengkapi penilaian pada silabus dengan penilaian sikap dan keterampilan, menambah sumber belajar selain dari buku cetak, menyesuaikan sintaks pada RPP dengan pendekatan saintifik dan AO disajikan pada saat yang tepat, menuliskan tujuan pada RPP dalam bentuk deskripsi dan memberikan gambaran proses pembelajaran serta pencapaian hasil belajar, menyediakan tempat pengerjaan soal pada LKPD, menyusun peta konsep dengan proposisi yang baik dan singkat dan menggunakan huruf kapital pada setiap option jawaban.

Selanjutnya, dilakukan penyebaran angket pada mahasiswa dan peserta didik sebagai data pendukung hasil validasi dari validator. Rata-rata respon dari mahasiswa pendidikan fisika dan peserta didik yaitu 99,67\% dan $100 \%$ yang berarti respon mereka sangat baik terhadap perangkat yang dikembangkan. Respon positif menunjukkan bahwa mahasiswa dan peserta didik dapat menerima dengan baik perangkat pembelajaran yang dikembangkan dan tertarik apabila perangkat tersebut diterapkan dalam pembelajaran fisika [31].

\section{KESIMPULAN}

Perangkat yang dikembangkan pada penelitian ini yaitu silabus, RPP dengan model AO, LKPD, peta konsep, instrumen tes penguasaan konsep dan instrumen tes retensi fisika. Setiap perangkat yang dikembangkan telah divalidasi untuk menjamin kualitasnya sebelum digunakan dalam pembelajaran. Hasil validasi setiap perangkat menunjukkan nilai CVI dan reliabilitas yang tinggi sehingga termasuk dalam kategori sangat layak dan reliabel. Penelitian ini hanya dibatasi sampai tahap develop yaitu validasi perangkat oleh validator, dan tidak dilakukan disseminate. Berdasarkan hasil 
validasi, diharapkan setiap perangkat yang telah dikembangkan dapat membantu meningkatkan penguasaan konsep dan retensi fisika peserta didik.

\section{UCAPAN TERIMA KASIH}

Ucapan terima kasih yang sebesar-besarnya penulis ucapkan kepada Dr. Ahmad Harjono, S.Si., M.Pd., Dr. Gunawan, S.Pd., M.Pd., dan Syahrial Ayub, S.Pd., M.Si. yang telah membimbing dalam penulisan artikel ini.

\section{DAFTAR PUSTAKA}

[1] Sugiana, I. N., Harjono, A., \& Gunawan G, "Pengaruh Model Pembelajaran Generatif Berbantuan Media Laboratorium Virtual terhadap Penguasaan Konsep Fisika Siswa pada Materi Momentum dan Impuls," Jurnal Pendidikan Fisika dan Teknologi, vol. 2, no. 2, 2016.

[2] Sinulingga, K., \& Munte, D, "Pengaruh Model Pembelajaran Advance Organizer Berbasis Mind Map terhadap Hasil Belajar Fisika Siswa pada Materi Pokok Besaran dan Satuan di Kelas X SMA," Jumal Pendidikan Fisika, vol. 1, no. 2, 2012

[3] Darman, D.R., Wibowo, F.C., Suhandi, A., \& Rusdiana, D, "Pembelajaran SAVIR (Somatic, Auditory, Visual, Intelelectual dan Repetition) dalam Mempertahankan Retensi Siswa Pokok Bahasan Asas Black dan Pemuaian," Gravity Jurnal Ilmiah Penelitian dan Pembelajaran Fisika, vol. 2, no. 1, 2016.

[4] Gazali, R.Y. "Pembelajaran Matematika yang Bermakna," Jurnal Pendidikan Matematika, vol. 2, no. 3, 2016.

[5] Sari, P.I., Gunawan, G., \& Harjono. A, "Penggunan Discovery Learning Berbantuan Laboratorium Virtual pada Penguasaan Konsep Fisika Siswa". Jurnal Pendidikan Fisika dan Teknologi, vol. 2, no. 4, 2016.

[6] Harjono, A, "Perbedaan Strategi Pembelajaran dan Pemberian Advance Organizer Pengaruhnya Terhadap Hasil Belajar Fisika Siswa Kelas X”, Jurnal Pijar MIPA, vol. 7, no. 1, 2012.

[7] Rahmatiah, R., Supriyono, K.H., \& Kusairi, S, "Pengaruh Scaffolding Konseptual dalam Pembelajaran Group Investigation terhadap Prestasi Belajar Fisika Siswa SMA dengan Pengetahuan Awal Berbeda" Jurnal Pendidikan Fisika dan Teknologi, vol. 2, no. 2, 2016.

[8] Wachanga, S.W, "Effect of Advance Organizer Teaching Approach on Secondary School Students Achievement in Chemistry in Maara District Kenyaeueurasra", Juornal of Mathematics Science and Technologi Education, vol. 2, no. 6, 2013.

[9] Mayer, R, "Learning and Instructions”. New Jersey: Pearson Education, Inc. 2008.

[10] Mika, J., Zainuddin, Z., \& Syubhan, A, "Penerapan Model Pembelajaran Advance Organizer untuk Meningkatkan Hasil Belajar Siswa", Berkala Ilmiah Pendidikan Fisika, vol. 2, no. 3, 2014.

[11] Nopiani, R., Harjono, A., \& Hikmawati, H, "Pengaruh Model Pembelajaran Advance Organizer Berbantuan Peta Konsep terhadap Hasil Belajar FIsika Siswa SMA Negeri 1 Lingsar", Jurnal Pendidikan Fisika dan Teknologi, vol. 3, no. 2, 2017.

[12] Trianto, T , "Model Pembelajaran Terpadu”, Jakarta: Bumi Aksara, 2010.

[13] Lawshe, C. H, "A Quantitative Approach to Content Validity" Journal of Personel Psychology: Purdue University, 1975.

[14] Borich, G. D, “Observation Skills for Effective Teaching”, New York: Merril, 1994.

[15] Riduwan, R, "Skala Pengukuran Variabel-variabel Penelitian" Bandung: Alfabeta. 2013.

[16] Sujadi, S, "Metode Penelitian Pendidikan”, Jakarta: Rineka Cipta, 2002.

[17] Nisyah, M., Gunawan, G., Harjono, A., \& Kusdiastuti, M, "Perangkat Pembelajaran Inkuiri Dipadu Advance Organizer (AO) untuk Meningkatkan Penguasaan Konsep dan Kemampuan Pemecahan Masalah Fisika Siswa", Jurnal Pijar MIPA, vol. 20, no. 10, 2019.

[18] Joyce, B., Weil, M., \& Calhoun, E, "Models of Teaching Edisi Kesembilan" Yogyakarta: Pustaka Pelajar, 2016.

[19] Ausubel, D.P, “Educational Psychology: A Cognitive View,” New York: Holt, Rinehart, and Winston, 1968. 
[20] Harjono, A., Gunada, I.W., Sutrio, S., \& Hikmawati, H, "Penerapan Advance Organizer dengan Model Pembelajaran Ekspositori Berpola Lesson Study Untuk Meningkatkan Hasil Belajar Fisika Peserta Didik," Jumal Pendidikan Fisika dan Teknologi, vo. 4, no. 1, 2018.

[21] Rahayu, S, "Pengembangan Model Pembelajaran Advance Organizer untuk Meningkatkan Aktivitas dan Hasil Belajar Siswa Pokok Bahasan Koloid," Journal of Innovative Science Education, vo. 1 , no. 1, 2012.

[22] Uno, H, "Psikologi Pendidikan," Jakarta: Bumi Aksara, 2006.

[23] Nugroho, I.R., \& Ruwanto, B, "Pengembangan Media Pembelajaran Fisika Berbasis Media Sosial Instagram sebagai Sumber Belajar Mandiri untuk Meningkatkan Motivasi dan Prestasi Belajar Fisika Siswa Kelas XI SMA," Jumal Pendidikan Fisika, vol. 6, no. 6, 2017.

[24] Putra, A., Syarifuddin, H., \& Zulfah, Z, "Validitas Lembar Keja Peserta Didik Berbasis Penemuan Terbimbing dalam Upaya Meningkatkan Pemahaman Konsep dan Kemampuan Penalaran Matematis," Jumal Riset Pendidikan Matematika, vol. 1, no. 2, 2018.

[25] Primadani, R., Tukiran, T., \& Jatmiko, B, "Pengembangan Perangkat Pembelajaran Fisika Model Structured Inquiry Untuk Meningkatkan Keterampilan Pemecahan Masalah Siswa Pada Materi Fluida Statis,"JPPS: Jurnal Penelitian Pendidikan Sains, Volume 6, Nomor 1, 2017.

[26] Alberta, C, "A Concept Mapping Tool to Handle Multiple Formalism Knowledge Science," Canada: Institute University of Calgary, 2005.

[27] Silaban, B, "Hubungan Antara Penguasaan Konsep Fisika dan Kreativitas dengan Kemampuan Memecahkan Masalah pada Materi Pokok Listrik Statis," Jurnal Penelitian Bidang Pendidikan, vol. 20, no. 1, 2014.

[28] Thahir, A., Rahma, D., \& Deby, P, “Advance Organizer Model in Physics Learning: Effect Size Test on Learning Activities and Students Conceptual Understanding," Journal of Physics, vol. 1467, no. 2020, 2019.

[29] Setiawan, A., Sutarto, A. \& Indrawati, I, "Metode Praktikum dalam pembelajaran Pengantar Fisika SMA: Studi Peta Konsep Besaran dan Satuan Tahun Ajaran 2012-2013," Jurnal Pendidikan Fisika, vol. 1, no. 3, 2012.

[30] Fatmawati, A, "Pengembangan Perangkat Pembelajaran Konsep Pencemaran Lingkungan Menggunakan Model Pembelajaran Berdasarkan Masalah untuk SMA Kelas X," Jurnal Edusains, vol. 4, no. 2, 2016.

[31] Sulardi, S., Nur, M., \& Widodo, W, "Perangkat Pembelajaran Fisika Model Problem Based Lerning (PBL) untuk Melatih Keterampilan Berpikir Kritis Siswa," Jurnal Pendidikan Sains, vol. 5, no. 1, 2015. 